\title{
Prognostic Significance of Alkaline Phosphatase Activity and Callus Volume in Operatively Treated Bone Fractures
}

\author{
Ante Muljačić1, Renata Poljak-Guberina², Ognjen Živkovića , Marko Guberina ${ }^{4}$, Matea Majstorović-Matejićc \\ ${ }^{1}$ Department of Traumatology, Sisters of Charity Hospital Center Zagreb, Croatia \\ ${ }^{2}$ Department of Dental Prosthetics, School of Medicine, University of Split, Croatia \\ ${ }^{3}$ Institute for Rehabilitation and Orthopedic Assistance, Clinical Hospital Center Zagreb, Croatia \\ ${ }^{4}$ Department of Oral Surgery, Dental Clinic Zagreb, Croatia
}

\begin{abstract}
A B S T R A C T
Total and bone alkaline phosphatase are indicators of bone formation, a process essential in bone healing. The aim of this study was to assess the relationship of both total and bone alkaline phosphatase with the course and features of healing in surgically treated long bone fractures as compared to the callus volume. In this study, total and bone alkaline phosphatase levels and the callus volume were measured in two patients with long bone fractures. Fracture healing was rapid in one patient and slow in the other. Depending on the healing outcome, on day 7 an increase in the case of slow healing and a decrease in the case of rapid healing was noted for both total and bone alkaline phosphatase. In the case of slow healing, the callus volume was significant whereas in the case of rapid healing the callus was almost invisible on day 7. This result indicates a possible prognostic significance of aforementioned clinical biochemical and radiographic parameters in the monitoring of long bone fracture healing.
\end{abstract}

Key words: alkaline phosphatase, callus volume, long bone fracture

\section{Introduction}

It has been known for many years that the enzyme alkaline phosphatase participates in biological processes of fracture healing. Clinical studies conducted by Silbermann $^{1}$ and Sarmiento ${ }^{2}$ indicate that alkaline phosphatase in healing procedures is involved only with one of its izoenzyme, bone type alkaline phosphatase.

In patients with bone disease, whether it is bone forming or bone matrix destruction, the activity of total alkaline phosphatase is increased and electrophoresis at izoenzymes or temperature inactivation can be demonstrated. The most of this increase is related to bone izoenzyme. ${ }^{3}$ Taniguchi et al. and Pagani et al. consider that alkaline phosphatase and some other serum markers such as osteocalcin, IGF-I and IGFBP, are in constant correlation to the bone healing process. ${ }^{4,5}$ Stoffel has shown that the bone healing is conditioned by the amount of alkaline phosphatase and fracture dimensions. ${ }^{6}$
Experimental studies have shown that basal phosphatase izoenzyme levels in osteoblastic and bone cells are proportional to callus formation. ${ }^{3,7}$ Clinical studies have also shown that bone izoenzyme of alkaline phosphatase in serum can determine the bone formation index. ${ }^{8,9} \mathrm{Ex}-$ periments on sheep's tibia showed similar correlations, although they had individual variations..$^{10,11}$ The analysis of alkaline phosphatase activity (ATP) is a standard laboratory procedure within contemporary research studies of fracture healing in humans beings. , $, 5,12^{2}$

Standard laboratory procedures consist of two different methods: alkaline phosphatase (ATP) and bone-specific alkaline phosphatase (BsALP) determination. ${ }^{13,14,15} \mathrm{An}$ analytical sample for determining the activity of alkaline phosphatase is a serum obtained by centrifugation of a blood sample without anticoagulants at $3500 \mathrm{rpm}$ for 10 minutes. The alkaline phosphatase activity analysis is 
performed immediately after separation, or at least 4 hours after the blood is removed, if the sample is at room temperature. For the determination of alkaline phosphatase, the Da Foncesca-Wolheim method is used according to the recommendations of the International Association of Clinical Chemistry (IFCC). As a substrate, 4-nitrophenylphosphate (4-NNP) is used, and aminomentylpropanol (AMP) acts as a phosphate accelerator. 16 Under optimized conditions, the alkaline phosphatase (ALP) present in the sample catalyzes the following reaction:

$$
\text { 4-NNP + } \mathrm{H}_{2} \mathrm{O} \text { - }
$$

The intensity of the 4-nitrophenoxide (4-NPO) coloration was measured at $405 \mathrm{~nm}$ and is proportional to the catalytic activity of alkaline phosphatase (ALP) in the sample. Adult reference values are: $\mathrm{N}=47, \mathrm{X}=67 \pm 20 \mathrm{U} / \mathrm{L}$ (47-87). After the total alkaline phosphatase (ALP) is determined, then follows the bone-specific alkaline phosphatase (BsALP) determination. The izoenzyme activity is determined according to the method described in 1984 by Rosalki i.Foo. ${ }^{17}$ This includes a Boehringer test containing lecithin from wheat germ $(2 \mathrm{~g} / \mathrm{L}$ lecithin in $5 \mathrm{mmol} / \mathrm{L}$ acetate buffer $\mathrm{pH}$ 4.5). At the beginning the bone alkaline phosphatase precipitates by the precipitating reagent. After 30 minutes of incubation at room temperature, the sample was centrifuged for six minutes at $4000 \mathrm{rpm}$. In the supernatant the remaining ALP activity is determined. The calculation is based on the difference between the total activity of ALP and the remaining activity of ALP in the supernatant results in the bone-specific alkaline phosphatase (BsALP). Reference values for adults are: $\mathrm{N}=50, \mathrm{X}=25 \pm 12 \mathrm{U} / \mathrm{L})$.

Studies show the correlation of alkaline phosphatase activity (AP) with the fracture dimensions and the callus volume. ${ }^{6,12}$ The increased activity of alkaline phosphatase during bone fracture treatment and the increase of bonespecific alkaline phosphatase has revealed the need for research and clarification of the clinical evaluation of the estimate of the bone fracture outcome.

Standard clinical procedures for determining bone healing includes the patient's subjective attitude, knowledge and experience of the responsible physician and radiological findings. Since the patient's attitude is subjective, evaluation of pain in the case of loading or pausing, it is considered unreliable. Radiological monitoring also depends significantly on the experience and subjective attitude of the radiologist and monitoring is of a long-term nature. Measurement of bone-specific alkaline phosphatase in the early post-traumatic period can point safely to the prognosis of stability of osteosynthesis, i.e. the rate of bone healing. ${ }^{18}$

The volume of callus after the osteosynthesis correlates with decreasing. and in the same way by increasing. the ALP and BsALP levels, suggesting that observation of changes in biochemical parameters of alkaline phosphatase and specific bone alkaline phosphatase and callus volume can predict the dynamics of bone healing. ${ }^{12}$
In this report we want to prove that the standard clinical procedures for determining bone healing with the value of bone-specific alkaline phosphatase and radiological procedures involving the measurement of the volume of the subperiosteal callus can provide a reliable prognosis for bone healing. We monitored two patients with different stability of bone fragments after osteosynthesis. We used standard laboratory methods for measuring alkaline phosphatase and radiological treatment described by Muljacic in his work. ${ }^{12}$

\section{Methods}

\section{Radiological procedure}

It is assumed that the activity of the bone-specific alkaline phosphatase depends on the extent of the fracture i.e. the bone fracture surface.

The bone fracture surface cannot be accurately determined by an X-ray chart. Therefore an approximate parameter is used. Those parameters include the projection length of the cracking gap, i.e. the sum of the length of all the projections of the fracture cracks. All these parameters are measured in millimeters. To avoid an error in increasing the X-ray image, this value is expressed as modular. (Figure 1).

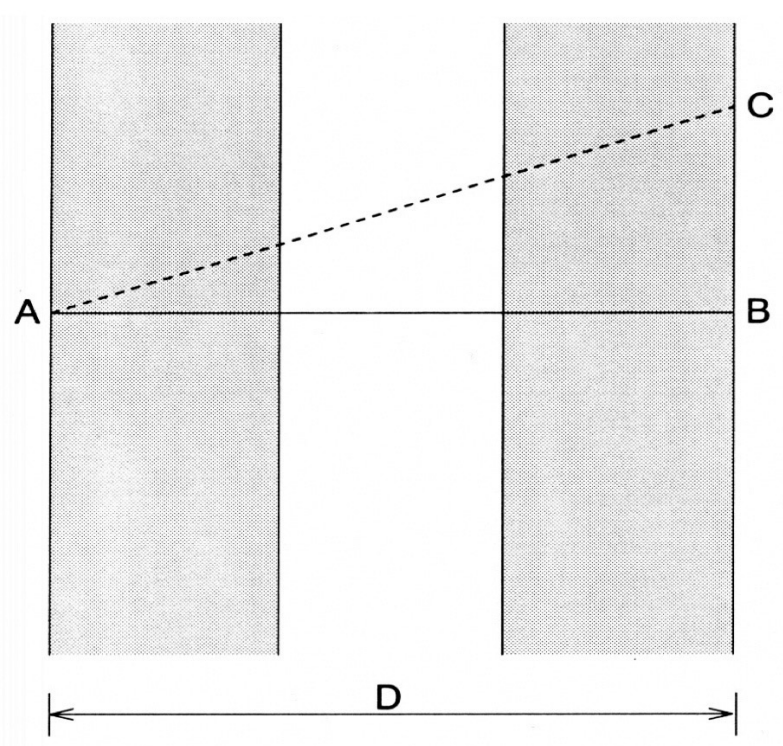

Fig 1. Schematic presentation of bone fracture. Bone diameter $D$ $-A B$. The length of the cracking gap - AC.

The higher the ratio, the more likely the breakage to be sidelong, or consist of more fractured fragments. With transverse fractions the ratio will be one by one. Larger cracking means greater mobility, greater breakage area, larger internal callus and larger bones construction, which could confirm the presumption of correlation between the extent of the fracture and the activity of the 
bone-specific alkaline phosphatase and the total alkaline phosphatase. The parameters for calculating the fracture extent, i.e. the fracture surface of the bones, were measured on the X-ray image. X-ray recording was done by standard method with standard film, standard exposure. Special attention is paid to the constant focus in order to maximize the bone image. Particular attention was also paid to the identical bone projection.

\section{Mathematical processing}

The volume of the periosteal callus was measured by the parameters shown in Figure 2. We have determined the length of the callus $\mathrm{L}$ (the length connecting the points where the callus elevation moves to the normal bone) and the height of the callus we have marked with $\mathrm{H}$ (the distance of the most exuberant part of the calluses to the line that would mark the outer subperiosteal surface of the cortex). Callus is usually spindle shaped, often irregular, and we used approximate mathematical methods to calculate its volume.

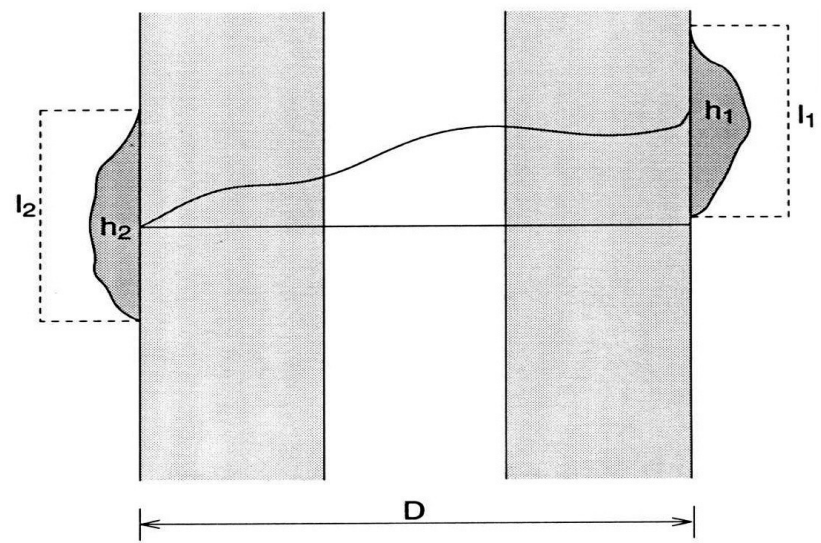

Fig 2. Schematic presentation of callus.L1, L2 = width; $h 1, h 2=$ height; $D=$ the center of gravity of the imaginary circle around which the triangle rotates.

The spindle projection of the callus can most often be approximated with the triangle. According to the formulas for the calculation of the triangle surface (Formula 1) a parameter has been obtained indicating the surface of the projection of calluses on one, or the other, side.

$$
\mathrm{P}=\frac{1}{2} \mathrm{Ixh}\left(\mathrm{mm}^{2}\right) \quad \text { Formula } 1
$$

$l=$ length of the callus i.e. the length connecting the point where the callus elevation goes to the normal bone

$\mathrm{h}=$ the height of the callus i.e. the distance of the most exalted part of the callus from the line of the outer subperiosteal surface of the cortex

The volume of the callus calculated by Formula 2 .

$$
\mathrm{V}=\frac{1}{2} \mathrm{hhD} \pi\left(\mathrm{mm}^{3}\right) \quad \text { Formula } 2
$$

$\mathrm{D}=$ the center of gravity of the imaginary circle around which the triangle rotates

If the surface of the rotating triangle $(\mathrm{P})$ is replaced by A, the formula looks like

$$
\mathrm{V}=\mathrm{AD} \Pi\left(\mathrm{mm}^{3}\right)
$$

Formula 3

The obtained formula corresponds to the assumption that the callus is equally developed on both sides of the $\mathrm{x}$-ray image. Since it is uneven, A is replaced with A1 + A2 and Formula 4 reads:

$$
\mathrm{V}=\frac{1}{2}(\mathrm{~A} 1+\mathrm{A} 2) \mathrm{D} \Pi
$$

Formula 4

The multiple X-ray images from different projections give more accurate approximation of the volume of the outer callus

$\mathrm{V}=\frac{1}{\mathrm{~N}} \quad(\mathrm{~A} 1+\mathrm{A} 2+\mathrm{A} 3+\mathrm{An}) \mathrm{D} \Pi \quad \mathrm{li} \quad \mathrm{V}=\frac{1}{\mathrm{~N}}$ AiD $\quad$ Formula 5

The $\mathrm{n}$ is the number of shadows projection of the callus, and Ai sums all the shadows.

The formation of a callus is apparent after a longer period i.e. after finishing of bone healing of the fracture. Our research confirms that measuring the alkaline phosphatase value and bone-specific alkaline phosphatase of the first, seventh and fourteenth days after the trauma may indicate the outcome and rate of bone fracture healing.

\section{Results}

\section{Patient 1}

A 43-year-old patient with tibial fracture. After osteosynthesis RTG control shows practically complete bone fragments stability. The alkaline phosphatase value on day 1 was $81 \mathrm{U} / \mathrm{L}, 7$ days $62 \mathrm{U} / \mathrm{L}, 14$ days $42 \mathrm{U} / \mathrm{L}$ and 21 days $34 \mathrm{U} / \mathrm{L}$ Changes in activity of bone-specific alkaline phosphatase were monitored on the same days. The values were: on the 1 st day $45 \mathrm{U} / \mathrm{L}, 7$, the 7 th day $9 \mathrm{U} / \mathrm{L}$, day 14 in $7 \mathrm{U} / \mathrm{L}$ and day 21 in $5 \mathrm{U} / \mathrm{L}$. RTG was found on the $1 \mathrm{st}, 7 \mathrm{th}$, 14 th and 21 st day to create a virtually invisible callus (Figure 3).

\section{Patient 2}

A 39-year-old patient with tibial fracture. After osteosynthesis RTG control shows instability of bone fragments. The alkaline phosphatase value was $128 \mathrm{U} / \mathrm{L}$ on Day One, Day 7195 U/L, Day 14257 U/L, and Day 21280 $\mathrm{U} / \mathrm{L}$. The value of the bone-specific alkaline phosphatase was $58 \mathrm{U} / \mathrm{L}$ on the first day, day $7,178 \mathrm{U} / \mathrm{L}$, day 14 , on $272 \mathrm{U} / \mathrm{L}$, and day 21 on $311 \mathrm{U} / \mathrm{L}$. The RTG on the $1 \mathrm{st}, 7 \mathrm{th}$, 14 th and 21 st day was found to create a callus that increased each day to make the volume $113 \mathrm{~cm}^{3}$ on day 21 (Figure 4). 

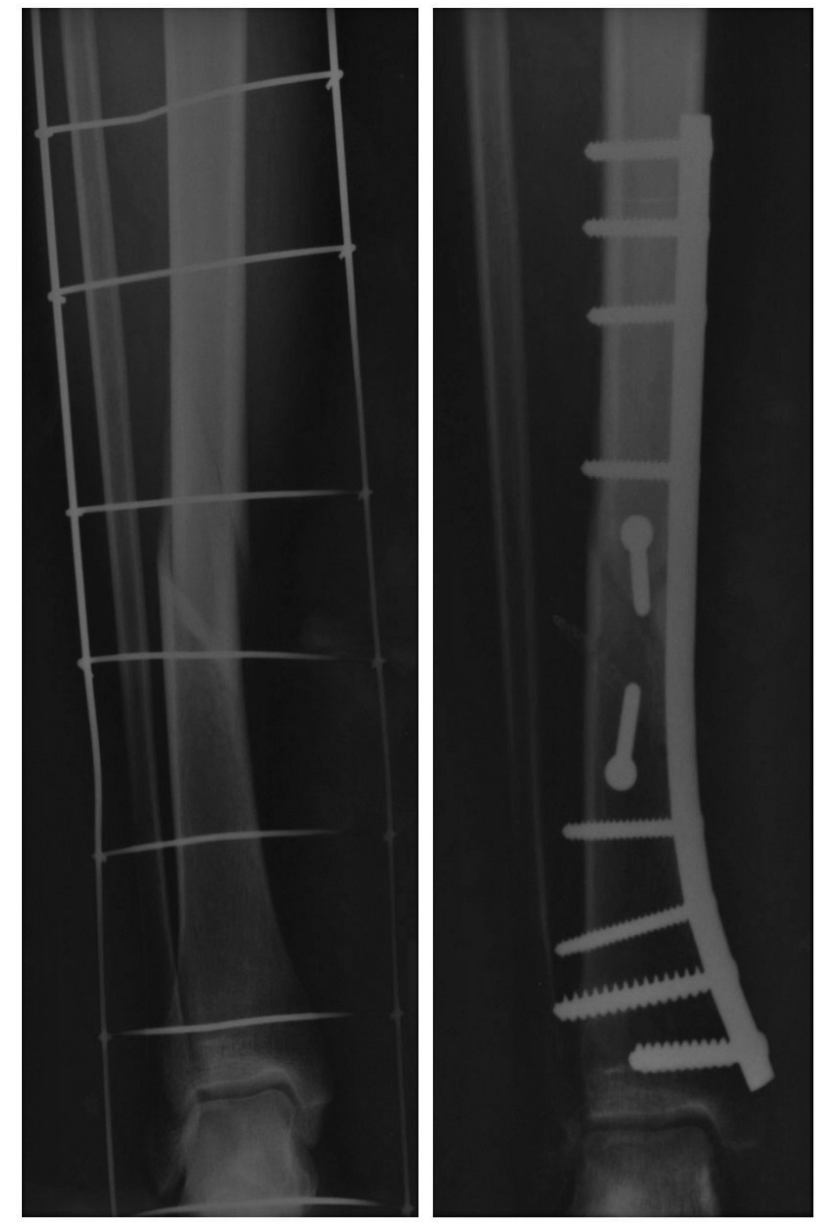

Fig 3. Bone fracture surgically treated. Stable osteosynthesis, rapid bone healing with a decrease in the value of alkaline phosphatase and bone-specific alkaline phosphatase, without radiologically visible callus formation.

\section{Discussion}

The analysis of our two cases and the monitoring of the healing of the surgically treated long bone fractures by measuring total and bone alkaline phosphatase, i.e. bone isoenzymes and callus volume calculated on the 1st, 7th, 14th and 21st day after trauma, showed the following:

- the coincidence of changes in total and bone alkaline phosphatase over the whole observed period, which was expected since the activity of bone alkaline phosphatase was calculated;

- depending on the outcome of healing, differences in total and bone alkaline phosphatase have been demonstrated already on the 7th day after the fracture;
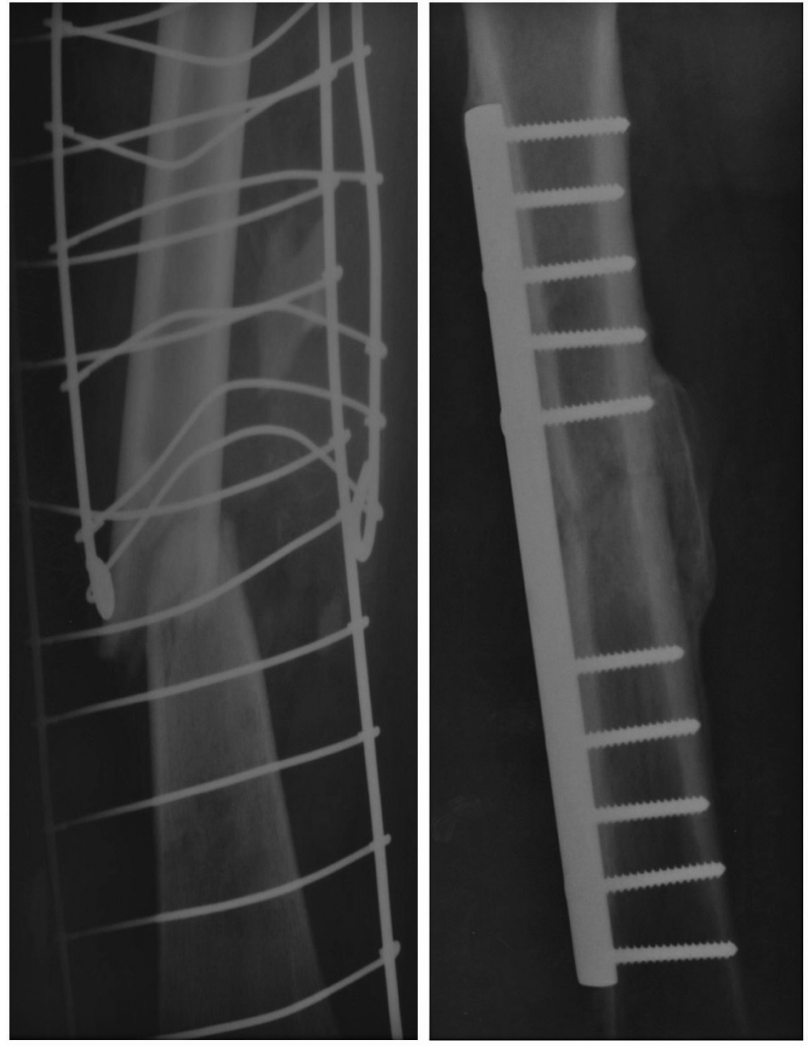

Fig 4. Bone fracture surgically treated. A non-stable osteosynthesis with slow bone healings, with an increase in the value of alkaline phosphatase and bone-specific alkaline phosphatase, with radiological visible large volume of callus $(113 \mathrm{~cm} 3)$.

- at rapid healing of the fracture already on the 7th day after the trauma, the activity of total and bone alkaline phosphatase is reduced;

- at slow healing of the fracture, a continuous increase in activity of total and bone alkaline phosphatase after the fracture is observed;

- the volume of callus was statistically significant and positively correlated with the values of total alkaline phosphatase and bone alkaline phosphatase after 1 and 7 days, both in fast and slow healing;

- the results of the study indicate the possible prognostic significance of callus volume and activity of bone and bone alkaline phosphatase in surgical treatments of long bone fractures, while the difference between slow and rapid healing in our examinations could be observed even after the 7 th day.

\section{REFERENCES}

1. SILBERMANNN M, TOISTER Z, LEWINSON D, Metab Bone Dis Rel Res, 3 (1981) 675. - 2. SARMIENTO A, LOTTA LL, Closed functional treatment of fractures (Berlin, Springer, 1981) - 3. FARLEY J, HALL S, HERRING S, TARBAUX N, MATSUYAMA T, WERGEDAL J,

Metaboloism, 40 (1986) 664. - 4. TANIGUCHI T, MATSUMOTO T, SHINDO H, Injury, 34 (2003) 477. — 5. PAGANI F, FRANCUCCI CM, MORO L, J Endocrinal Invest, 28 (2005) 8. - 6. STOFFEL K, ENGLER H, KUSTER M, RIESEN W, Clin Chem, 53 (2007) 131. — 7. FARLEY J, 
BAYLINK D, Metabolism, 35 (1986) 563. - 8. KJAERSGAARD-ANDERSEN P, PEDERSEN P, KRISTENSEN SS, SCHMIDT SA, PEDERSEN NW. Clin Orthop, 234 (1988) 102. - 9. VAN STRALEN JP, SANDERS E, PRUMEL MF, SANDERS GT, Clin Chim Acta, 201 (1991) 27. - 10. SEEBECK P, BAIL HJ, EXNER C, SCHELL H, MICHEL R, AMTHAUER H, BRAGULLA H, DUDA GN, Bone, 37 (2005) 669. - 11. KLEIN P, BAIL HJ, SCHELL H, MICHEL R, AMTHAUER H, BRAGULLA H, DUDA GN, Calcif tissue Int, 75 (2004) 40. - 12. MULJAČ́IĆ A, Aktivnost alkalne fosfataze u bolesnika s prijelomima kostiju (Doctoral dissertation, Zagreb, 2006). - 13. BOGDANOVA M, Clin Chem Lab Med, 37 (1999) 1. — 14 NAKAGAWA H, KAMIMURA M, TAKAHARA K, HASHIDATE $\mathrm{H}$, KAWAGUCHI A, UCHIYAMA S, MIYASAKA T, J Orthop Sci, 11 (2006) 135.- 15. WÖLFL C, SCHUSTER L, HÖNER B, ENGLERT S, KLEIN R, HIRCHE C, MÜNZBERG M, GRÜTZNER PA, KNESER U, HARHAUS L, GMS Interdiscip Plast Reconstr Surg DGPW, 18 (2017) 17. DOI:
10.3205/iprs000119.eCollection 2017 - 16. Z Klin Chem Klin Biochem, 19 (1972) 101. - 17. ROSALKI SB, Clin Chim Acta, 226 (1994) 143. - 18 MULJAČIĆ A, POLJAK-GUBERINA R, TURČIĆ J, ŽIVKOVIĆ O, GUBERINA M, KLAIC B, Croat Chem Acta, 83 (2010) 315. - 19. MUKHOPADHYAY M, SINHA R, PAL M, BHATTACHARYYA S, DAN A, ROY MM, Indian J Clin Biochem, 26, 3 (2011) 274. DOI: 10.1007/s12291-011 0143-1. - 20. Gundberg CM, Clin Lab Med, 20, 3 (2000) 489. - 21. ŠPIČEK-MACAN J, HUDOBA N, KOLARIĆ N, Coll Antropol, 34 (2010) 1461. - 22. JONOVSKA S, ŠENGULA JENGIĆ V, KVESIĆ A, Coll Antropol, 32 (2008) 1121. - 23. MULJAČIĆ A, POLJAK-GUBERINA R, TURČIĆ J, ŽIVKOVIĆ O, GUBERINA M, KLAIC B, Croat Chem Acta, 83 (2010) 315. - 24. GU H, LI Z, LV XF, ZHAO AB, ZHU MY, ZHANG Y, Eur Rev Med Pharmacol Sci, 23 (2019) 4575. DOI: 10.26355/eurrev-201906-18034.

\section{R. Poljak Guberina}

Department of Dental Prosthetics, School of Medicine, University of Split, Šoltanska 2, 21000 Split, Croatia e mail:poljak@sfzg.hr

\section{PROGNOSTIČKO ZNAČENJE AKTIVNOSTI ALKALNE FOSFATAZE I VOLUMENA KALUSA KOD KIRURŠKI ZBRINUTIH PRIJELOMA}

\section{S A Ž E T A K}

Aktivnosti ukupne i koštane alkalne fosfataze povezane su s procesima izgradnje kosti, nužnih kod cijeljenja prijeloma. Svrha našeg istraživanja bila je ispitati povezanost ukupne i koštane alkalne fosfataze s tijekom i osobitostima cijeljenja kirurški zbrinutih prijeloma dugih kostiju u korelaciji sa volumenom stvorenog kalusa. U ovom istraživanju aktivnost ukupnog i koštanog izoenzima i količina stvorenog kalusa određivana je kod dvaju pacijenata s prijelomom dugih kostiju. Jednog ispitanika karakterizira brzo cijeljenje koštanog prijeloma, a drugog sporo cijeljenje koštanog prijeloma. Rezultati ovog istraživanja pokazali su da je ovisno o ishodu, već 7-og dana došlo do porasta vrijednosti aktivnosti ukupne i koštane alkalne fosfataze kod sporog, odnosno do opadanja kod brzog koštanog cijeljenja. Također kod sporog cijeljenja vidljiv je značajan kalus, dok kod brzog cijeljenja 7-og dana kalus je bio gotovo nevidljiv. Ovaj rezultat ukazuje na moguću prognostičku vrijednost navedenih kliničkih biokemijskih i rendgenskih parametra u praćenju uspješnosti kirurškog cijeljenja prijeloma dugih kostiju. 
